\title{
Some Difficulties and Limitations in the Implementation of the Law on Handling of Administrative Violations
}

\author{
Ho Duc Hiep \\ Hanoi University of Home Affairs in Ho Chi Minh City, Vietnam, No. 181, Le Duc Tho Street, Ward 17, Go Vap \\ District, Ho Chi Minh City
}

\section{*Corresponding Author}

Ho Duc Hiep

\section{Article History}

Received: 20.09.2020

Accepted: 28.09 .2020

Published: 02.10.2020

\begin{abstract}
Administrative handling activities involve more than 25 groups of subjects with sanctioning competence in more than 56 different fields of state management [1]. Administrative violations have violated the State's administrative order and management, affecting the situation of social security and safety. Therefore, the handling of administrative violations has a very important meaning in state management activities in order to maintain administrative order and discipline in the socio-economic life, which is the basis to ensure social justice and strengthen the socialist legislation. However, in recent years, the handling of administrative law violations has faced some difficulties. On the basis of a contrasting comparison of a number of provisions in sanctions and violations, the study has pointed out the limitations in the implementation process from which proposing solutions to perfect the handling law administrative violations in Vietnam.
\end{abstract}

Keywords: Law on handling administrative violations, Handling violations, Difficulties and limitations, Vietnam.

\section{INTRODUCTION}

When conducting state administrative management, social relations arise between the managing entities and the managed objects that need to be regulated by the state - that is, the state administrative relations. These relationships appear very popular in everyday life, so setting out legal regulations to regulate these social relations is an inevitable and objective part of the management process. In order for these regulations to be effective, it is necessary to strictly observe the subjects when participating in state administrative management.

Administrative violation is one of the most common types of violations of the law in general. Therefore, sanctioning for violating the administrative law is essential in order to limit the administrative violations occurring in everyday life. Administrative sanctions are activities of competent individuals in order to determine acts of administrative violations in order to apply sanctions and other coercive measures prescribed by law to individuals, organizing acts of administrative violations. Like other legal liability prosecutions, the sanction of administrative violations must comply with certain principles to properly and accurately sanction and protect the rights and interests of the State and society. At the same time, it still effectively protects the legitimate rights and interests of the sanctioned individuals and organizations. However, in the implementation process, there were some difficulties and limitations due to many reasons. This study shows that there is a lack of coherence between law and sub-law documents; In the implementation process, there is still confusion between the administrative violation with a number of other legal violations; At the same time, it pointed out some shortcomings of the law on handling of administrative violations; Since then, it is recommended to change a number of articles to suit the practical situation of the country.

\section{Literature RivieW}

When it comes to the law to sanction administrative violations, one of the top issues that need to be addressed is the basis of administrative sanctions. The basis for the sanctioning of administrative violations is the act of administrative

Copyright @ 2020: This is an open-access article distributed under the terms of the Creative Commons Attribution license which permits unrestricted use, distribution, and reproduction in any medium for non commercial use (NonCommercial, or CC-BY-NC) provided the original author and source are credited. 
violation prescribed by law. The research on the concept of administrative violation has both important theoretical significance and profound practical nature, because only when the correct definition of the administrative violation can be determined specific administrative violations in each field of state management. If the correct administrative violation is determined, i.e. the right basis for the sanction is determined, the implementation of administrative sanctions can ensure the accuracy and ensure the legitimate rights and interests of the State and the group organizations and individuals, to promote the efficiency and the purpose of administrative sanctions is to restore the compromised state management order, contribute to education, offenders, and to prevent and prevent violations in the future, to avoid arbitrary administrative sanctions.

In the current system of legal regulations in Vietnam, the administrative violation is generally understood most generally as a violation of the State's management rules, but it is not a crime [1]. To distinguish a certain act that can be handled according to administrative procedures or criminally, it will be based on the signs and elements that make up that act. The acts of violating the criminal law will be penalized with penalties if the conditions are met. In addition, acts that satisfy the conditions and regulations of the administrative violations will be handled by administrative sanctions.

The law on handling of administrative violations in Vietnam has existed for a long time and has been supplemented and adjusted over time, each period has different regulations and definitions of administrative violations. Before our country issued the Ordinance on Sanctioning of Administrative Violations in 1989 [2], in Vietnam, the term "micro scene" was recognized [3]. This term is specified in the "Regulation on penalties for violations" issued together with Decree No. 143/CP of the Government Council dated May 27, 1977. Accordingly, "the scene" is defined as "the acts of infringing upon the social order and safety, which are simple, clear and the consequences are not serious, not to the extent of being examined for criminal liability or applying using other administrative measures is the scope of the scene "[1]. Also according to the provisions of the Regulation on sanctioning of the micro scene, there are 04 forms of punishment, namely: warning; a fine of from 1 to $10 \mathrm{VND}$; penalty for public labor from 01 to 03 days; imprisonment from 01 to 03 days. Thus, for the first time, the law stipulates acts that violate the social order and safety, but not to the extent of being examined for criminal liability, the measure "violating scene" will be applied. With this provision, it can be seen that the "micro scene" is a simple sanctioning measure for violations of the law but not to the extent of being examined for penal liability, or can be understood as legal violations civil law.

The concept of "administrative violations" was first regulated, the official definition in legal documents in Vietnam was in the Ordinance on Sanctions of Administrative Violations in 1989 [2]. Accordingly, it is an act done intentionally or unintentionally by individuals or organizations, violating the State management rules but not a criminal offense and under the provisions of law, must be administratively sanctioned". Although the 1989 Ordinance on Sanctioning of Administrative Violations officially introduced the concept of administrative violations, this concept only stipulates that administrative violations are acts "violating the rules of State management". It is not a violation of the law.

When our country issued the Ordinance on Handling of Administrative Violations in 1995, the concept of administrative violations was no longer officially recognized. Instead, the law provides for the concept of "administrative sanctions" and "administrative handling measures". Accordingly, "administrative sanctions are applied to individuals and organizations that intentionally or unintentionally violate the rules of state management, but not to the extent of being examined for penal liability and according to regulations the law must be administratively sanctioned "while" other administrative handling measures are applied to individuals who violate the law on social security, order, and safety, but not to the extent of prosecution save criminal liability" [4]. With these regulations, the concept of "administrative violation" is no longer directly regulated.

The 2002 Ordinance on the handling of administrative violations did not once again directly stipulate the concept of "administrative violations", but continued to introduce two concepts "sanctioning administrative violations" and "measures to handle violations administrative violation" is like the provisions of the 1995 Ordinance on Handling of Administrative Violations. Accordingly," sanctioning of administrative violations are applied to individuals, agencies, organizations that have intentional or unintentional acts. The intention to violate the provisions of the law on state management is not a crime and must be administratively sanctioned in accordance with the law "and" other administrative handling measures are applied to individuals. Committing a violation of the law on social security, order, and safety but not to the extent of being examined for penal liability. Under this definition, an administrative violation is understood as an intentional or unintentional act of an individual. Organizing, violating the provisions of the law on state management is not a crime and under the provisions of the law must be sanctioned for administrative violations" [5].

With the description of two different concepts that do not directly stipulate what is an "administrative violation" as defined in the 1989 Ordinance on Sanctions for Administrative Violations and to overcome these shortcomings, the Law the handling of administrative violations in 2012 has defined, clearly defined administrative violations as follows: "Administrative violation is an act of error committed by individuals or organizations, violating the provisions of law on 
state management which is not a crime and under the provisions of the law must be sanctioned for administrative violations "[1]. This is the most complete definition of an administrative violation and is used up to now. In addition to the concept of administrative violations according to the provisions of the 2012 Law on the handling of administrative violations, the current concept of administrative violations is also given as follows:

"Administrative violation is an act (act or inaction) that is illegal, at fault (intentional or unintentional) by an individual with the capacity to take responsibility for the administrative act or organization, to violate the state and social self-management, order of management and ownership of the State, organizations, and individuals, infringing upon the rights, freedoms and legitimate interests of people and citizens according to regulations of the law must bear administrative responsibility "[1].

Thus, the concept of administrative violation over time differs in terms of both words and regulations. However, the common point of the provisions on administrative violations of the Ordinance on Sanctions of Administrative Violations 1989, the Ordinance on Handling of Administrative Violations in 1995, the Ordinance on Handling of Administrative Violations in 2002, and the Law on Handling of Violations in 2012, the nature of the thing that shows the administrative violation is the simple law violation. However, the problem is not to the point of being handled criminally according to the law. Agreeing with this opinion, author Bui Tien Dat [6] wrote: "The definition of administrative violation can be seen in the Ordinance on sanctioning handling of administrative violations 1989, 1995, 2002 and the Law on the handling of violations administrative violations in 2012 are different in the language of expression but similar in nature".

\section{Some Difficulties and Limitations in Implementing the Law on Handling of Administrative Violations}

In Article 125 of the Law on the handling of administrative violations, provisions on the temporary seizure of material evidence, means, permits, professional practice procedures according to administrative procedures. This provision does not include business registration certificates, business registration certificates, identity cards, identity cards, in addition to additional sanctions of decrees such as the Decree. No. 158/2013/ND-CP dated 12/11/2013 regulating sanctioning of administrative violations in the fields of culture, sports, tourism, and advertising; Decree No. 28/2017/ND-CP dated 20/3/2017 of the Government amending and supplementing a number of articles of Decree No. 131/2013/ND-CP dated October 16, 2013, of the Government providing administrative penalties on copyright and related rights and Decree No. 158/2013/ND-CP do not stipulate that agencies competent to handle administrative violations are entitled to temporarily seize material evidence and means of violations during the mission. This situation has caused many difficulties, especially the specialized inspection agency in ensuring the observance of decisions on sanctioning administrative violations.

Point c, Clause 4, Article 52 of the Law on the handling of administrative violations states that "if the act falls under the sanctioning competence of many people in different branches, the sanctioning competence belongs to the chairperson of the People's Committee at the competent level. the right to sanction the place where the violation occurs "; However, at Point b, Clause 7, Article 10 of Circular No. 78/2016/TT-BQP, "in case of administrative violation, there are both acts under the sanctioning competence of the Border Guard and the act falls under the jurisdiction of the Border Guard. For another agency, the person with sanctioning competence in the border guard shall issue a sanctioning decision for an act falling under the sanctioning competence of the border guard and concurrently send a document on the transfer of dossiers, exhibits, and means administrative violations are not under the sanctioning competence of the border guards for competent agencies", these two contents contradict each other.

Article 122 of the Law on the handling of administrative violations and Decree No. 112/2013/ND-CP dated October 2, 2013, of the Government, amending and supplementing a number of articles of Decree No. 17/2016/ND-CP regulations the intention to detain people according to administrative procedures is only applicable in 03 cases; The detention period must not exceed 12 hours, in necessary cases, it may be extended but not more than 24 hours, for persons violating the border regulations or committing administrative violations in remote, remote mountainous areas. For islands, the time limit may be extended but not exceed 48 hours. However, in reality, there are many cases where administrative offenders store and transport suspected drugs, explosives, firecrackers, etc., requiring inspection, and the management of violators. While waiting for the assessment results to face many difficulties (Article 208 of the 2015 Criminal Procedure Code 2015 stipulates the time limit for assessment of drugs and explosives, etc. does not exceed 9 days) [7].

Clause 1, Article 3 of the Law on the handling of administrative violations states "One administrative violation will be sanctioned only once". Meanwhile, at Point b, Clause 1, Article 10 of the Law, the aggravating factor is "repeated administrative violations, recidivism". The above provisions on the principles of handling administrative violations are unclear and inconsistent; causing confusion and problems in the implementation process. For administrative violations that are repeated many times and at different times, the provisions of Point b, Clause 1 of Article 10 (considered as an 
aggravating factor) shall apply or be sanctioned from time to time violating the provisions of Clause 1, Article 3 of the Law on the handling of administrative violations.

Regarding the exercise of the right to accountability, according to Clause 1, Article 61 of the Law on the handling of administrative violations: "For acts of administrative violations that are prescribed by law to apply the sanction of deprivation of the right to use permits, practicing certificate for a definite term or suspending operation for a definite time or applying a maximum fine level of the fine bracket for such acts is VND 15,000,000 or more on individuals, from VND 30,000,000 or more for organizations, violating individuals, organizations have the right to explain directly or in writing to the persons with competence to sanction administrative violations, etc.". Provisions of the maximum fine level for organizations and individuals to have such accountability is not specific, with many different interpretations, leading to inconsistent application.

Regarding the confiscation of material evidence and means of administrative violations, Article 26 of the Law on the handling of administrative violations stipulates: Confiscation of material evidence and means of administrative violations is the addition to the State budget of objects, money, and goods and means directly related to administrative violations, applicable to serious administrative violations caused by intentional faults of individuals and organizations. Thus, the confiscation of administrative violation material evidence and means only applies to serious administrative violations caused by intentional faults of individuals and organizations. However, the reality is that in many cases, the individual or the organization transporting the goods but is not known (exactly, actually) is what to transport, it is difficult to prove the behavior due to intentional error. Although the extent of the violation is serious.

Regarding the time limit for execution of a decision to sanction an administrative violation, according to Clause 2, Article 68 of the Law on the handling of administrative violations: "The time limit for implementing a decision is 10 days from the date of receiving the sanctioning decision; In case the sanctioning decision has the execution duration of more than 10 days, such time limit will be followed". In cases where violating individuals or organizations fail to comply with decisions on sanctioning administrative violations, they may be coerced to comply with the provisions of Section 3 , Chapter III of the Law on the handling of administrative violations. However, at Point 1, Clause 1, Article 68 of the Law on the handling of administrative violations, the right to complain and initiate lawsuits against administrative sanctioning decisions of individuals and organizations is one of the basic contents in the enforcement of the law on handling of administrative violations. Under the provisions of the Law on Complaints and the Law on Administrative Procedures 2015 , in case of disagreement with the administrative sanctioning decision of a state agency or a competent person, individuals or organizations have the right to complain or sue; Complaints or lawsuits comply with the order and procedures prescribed by law.

In addition to the contradictions and inconsistencies between the Law on handling of Administrative Violations and relevant documents, many provisions in the Law on Handling of Administrative Violations are unfeasible, even impossible to implement in practice as:

Regarding the time of the temporary seizure of material evidence in Clause 3, Article 60 of the Law on the handling of administrative violations: "The time limit for temporary seizure of material evidence for value determination does not exceed 24 hours from the time of issuance of the decision on temporary seizure, in case it is absolutely necessary, the time limit may be extended but must not exceed 24 hours". Thus, the time of the temporary seizure of material evidence for maximum value determination does not exceed 48 hours is unsuitable with reality because the detention time is too short, due to the establishment of a valuation council, especially in cases of If the material evidence are smuggled goods with many types, the time is not enough for valuation according to regulations.

Clause 1, Article 66 of the Law on the handling of administrative violations states that "persons with competence to sanction administrative violations must issue decisions to sanction administrative violations within 07 days from the date of making written records of administrative violations main". This provision is understood that within 07 days (including holidays, days off) from the date of making a record, the competent person must issue a decision to sanction the administrative violation. However, there are some cases where the person making a record of administrative violations at the commune level, but the act falls under the sanctioning competence of the chairperson of the district or provincial People's Committee, in this case, the record maker must complete, transfer all related documents to the person authorized to make a decision. For communes with difficult travel conditions, it takes a long time to send dossiers, then the person making the sanction decision will have difficulty in ensuring the time.

In Clauses 3 and 5, Article 90, prescribing the subjects applying the measure of education at communes, wards or townships; Clause 4, Article 92 stipulates that the subjects are sent to reformatory schools; Clause 1, Article 94 stipulates that subjects are sent to compulsory education establishments: "violating the social order and safety twice or more in 06 months but not to the extent of being examined for penal liability". In fact, the application conditions are very 
difficult to implement because the time of 02 or more violations in 06 months is too short, it is very difficult to have the subjects to apply this measure.

In Clause 1, Article 122, the temporary detention of persons is applicable only in cases where it is necessary to immediately stop or suspend acts that disturb public order, cause injury to others or have grounds to believe that smuggling and illegally transporting goods across the border. However, in reality in the border areas, there are many cases where administrative offenders have an unclear identity, need time to verify their identity, whether to repeat or not to repeat the offense, etc, the handling violators to ensure that the handling of administrative violations faces many difficulties, especially in the absence of papers, means, and properties for the execution of decisions on sanctioning administrative violations.

\section{The Need to Amend and Supplement the Law on the Handling of Administrative Violations}

Over the past years, our country's socio-economic situation has many changes, the law violation situation has also evolved complicatedly, and many new real problems arise that need adjustment.... The review and assessment of current regulations on the handling of administrative violations after 05 years of implementation show that some current regulations are no longer appropriate and have not met the requirements of the house management nation in a new situation.

On the basis of research and a comprehensive assessment of the current legal system together with the results of the review of the implementation of the Ordinance, it shows that the content of the revised Ordinance this time needs to focus on solving three groups of questions subject: First is to amend existing regulations to meet state management requirements; the second is to recognize some provisions of new laws that have provisions on sanctioning of administrative violations to facilitate implementation and finally add some new regulations to handle violations comprehensive administration [8].

In addition, the process of applying the provisions of the law on handling of administrative violations of agencies, competent persons in making minutes of administrative violations, in issuing decisions to handle administrative violations also There are many errors and limitations such as: determining the violation while making the administrative violation minutes inaccurately, citing the violation that is not specified in the Government's Decrees on sanctions. administrative violation or determination of this violation but it leads to other violation terms, leading to lack of basis for issuing a sanctioning decision; delayed issuing decisions to sanction administrative violations after making records; failing to notify the right of explanation to the violator or issue a decision without the expiration of the time limit for the explanation; determine the authority to impose penalties in contravention of regulations; issuing decisions beyond the sanctioning competence; a number of cases have passed the time limit for execution of the decision but have not yet been enforced; the improper application of the fine level; the application of the forms in the filing of documents for handling administrative violations is not in accordance with regulations, etc. the above reasons have affected the efficiency of law implementation on the handling of administrative violations.

\section{CONCLUSION}

In order to further improve the effectiveness of the management of administrative handling, in the coming time, agencies, units, and localities are requested to further strengthen the enforcement of the law on handling of violations. administrative; continue to propagate and disseminate the provisions of the Law on Handling of Administrative Violations and relevant legal documents by appropriate forms and measures to raise people's awareness of law observance; organize specialized training courses on administrative handling in agencies, units, and localities in order to improve professional skills in handling administrative violations for individuals competent to handle violations administrative violation, restricting errors in the order of procedures and contents when issuing decisions to sanction administrative violations.

At the same time, it is recommended that competent agencies increase investment in technical and professional facilities and equipment serving law enforcement on the handling of administrative violations, especially investment in technology information in patrol, control, and handling of violators as well as state management in law enforcement on the handling of administrative violations. Strengthen patrol, control, timely detect, and handle acts of administrative violations to ensure the right competence, order, and procedures according to law. Pay attention to the implementation of decisions on administrative sanctions in order to ensure the strictness of the law and improve the effectiveness and efficiency of state management.

In addition, it is suggested that the Government soon stipulate the regulation rate of the revenues from sanctioning administrative violations for the agencies with competence to handle administrative violations in order to ensure the operation of the sanctioning force administrative. 
Through practice, continue to detect shortcomings of the legal document system on the handling of administrative violations to propose competent agencies to amend and supplement to ensure the legal system of handling administrative violations are increasingly perfect, unified, and highly feasible in practice. Agencies competent to increase human resources, invest in technical facilities and equipment, serving the enforcement of the law on handling of administrative violations, especially investment in information technology information in patrol, control, and handling of violators as well as state management in law enforcement on the handling of administrative violations.

\section{REFERENCES}

1. National Assembly of the Socialist Republic of Vietnam. (2012). Law on handling administrative violations.

2. The State Council. (1989). Ordinance on the handling of administrative violations.

3. Government Council. (1977). The regulation of sanctioning "micro scene" was issued together with Decree No. $143-$ CP of May 27, 1977.

4. National Assembly Standing Committee. (1995). Ordinance on handling of administrative violations.

5. National Assembly Standing Committee. (2002). Ordinance on handling of administrative violations.

6. Dat, B. T. (2017). Vietnamese civil law textbook. Hanoi: Hanoi National University.

7. National Assembly of the Socialist Republic of Vietnam. (2008). Criminal Procedure Code.

8. Government of the Socialist Republic of Vietnam. (2013). The Decree details a number of articles and measures to implement the Law on Handling of Administrative Violations. 